1969

\title{
The Insanity Defense in English-Speaking African Countries
}

Michael L. Perlin

New YorkLaw School, michael.perlin@nyls.edu

Follow this and additional works at: https://digitalcommons.nyls.edu/fac_articles_chapters

8. Part of the Criminal Law Commons, and the Law and Psychology Commons

\section{Recommended Citation}

African Law Studies, Vol. 2, pp. 73-92

This Article is brought to you for free and open access by the Faculty Scholarship at DigitalCommons@NYLS. It has been accepted for inclusion in Articles \& Chapters by an authorized administrator of DigitalCommons@NYLS. 


\section{THE INSANITY DEFENSE IN \\ ENGLISH-SPEAKING AFRICAN COUNTRIES}

Michael L. Perlin

The ordinary test of criminal responsibility is whether the defendant can tell right from wrong. . . The application of [this] test to a borderline case can be nothing more than a moral judgment that it is just or unjust to blame the defendant for what he did. Legal tests of criminal insanity are not and cannot be the result of scientific analysis of objective judgment. . . The ordinary sense of justice still operates in terms of punishment. . . A man who cannot reason cannot be subject to blame.

The modern science of psychology . . does not conceive that there is a separate little man in the top of one's head called reason whose function it is to guide another unruly little man called instinct, emotion or impulse in the way he should go. . . To the psychiatrists mental cases are a series of imperceptible gradations from the mild psychopath to the extreme psychotic, whereas criminal law allows for no gradations and requires a final decisive moral judgment of the culpability of the accused. For the purposes of conviction there is no twilight zone between abnormality and insanity. An offender is wholly sane or wholly insane.

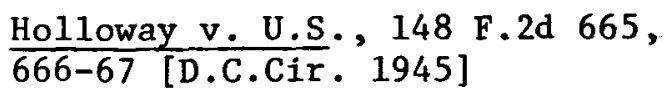

This statement by the District of Columbia Court of Appeals predated by some nine years the famed Durham v. U.S. and by another seven years the significant U.S. v. Currens decisions. Its basis in fact has been recognized by professors, ${ }^{1}$ psychiatrists, ${ }^{2}$ and judges. ${ }^{3}$ Yet, its

${ }^{1}$ Goldstein and Katz, "Abolish the Insanity Defense-Why Not?" 72 Yale L.J. 855 (1963).

Menninger, The Human Mind (1937).

3. S.S. v. Freeman, 357 F.2d 606 (2d C1r. 1966). 
significance--and its basis in truth--have gone 1argely ignored in the English speaking countries of Africa. Included in this study are Ethiopia, Gambia, Ghana, Kenya, Liberia, Malawi, Nigeria, Sudan, Sierra Leone, Tanzania, Uganda and Zambia. With several significant exceptions, these countries retain the test of the M'Naughten case of determining criminal responsibility: whether the defendant can tell right from wrong. ${ }^{4}$ This fact, when seen in light of the negligible number of practicing psychiatrists in Africa, points up a glaring need in that continent for new developments in the field of criminal law, the insanity defense, and the problems of responsibility.

Any attempt to make a comparative study of such a subject area in Africa is at once made more difficult by the general lack of law codification. Statutory, case and secondary source material--where available--must all be independently researched before any cohesive analysis can be begun.

For the purposes of this paper, the countries of Africa will be divided into three broad categories: those which follow a strict M'Naughten Rule, those which follow a more relaxed version of $M^{\prime}$ Naughten and/or accept the defense of irresistible impulse, ${ }^{6}$ and those which appear to have, in large measure, rejected the traditional test. As each country is analyzed, in addition, the available bibliography of cases, statutes, and commentaries will be reviewed.

4"It must be clearly proved that at the time of committing the act, the party accused was laboring under such a defect of reason, from disease of the mind, as not to know the nature and quality of the act he was doing or, if he did know it, that he did not know he was doing right from wrong." M'Naughten's Case, 8 Eng. Rep. 718,722 (1843).

${ }^{5}$ A recent study accounted for only twenty-six south of the Sahara, ten of whom were in Nigeria. Milner, African Penal Systems, 320 (1969).

${ }^{6}$ See, e.g., Smith V. U.S., 36 F.2d 549 (D.C. Cir. 1929). 


\section{Pure M'Naughten}

GAMBIA

Gambia is among the countries that have retained a practically pristine version of the M'Naughten Rule. Its statute reads:

A person is not criminally responsible for an act or omission if at the time of doing the act or making the omission he is through any disease affecting his mind, incapable of understanding what he is doing or of knowing that he ought not to do the act or make the omission.

But a person may be criminally responsible for an act or omission although his mind is affected by disease

if such disease does not in fact produce upon his mind one or another of the effects above mentioned in reference to that act or omission. [Laws of Gambia, ch. 37, sec. $10(1967)$.

No reported cases could be found interpreting this statute, which is worded identically to the laws of many other African nations. ${ }^{7}$ on its face it appears to be strictly within the confines of M'Naughten, without any consideration of the psychiatric or legal propositions which have gone to effectively blunt the force of $M$ 'Naughten in many American jurisdictions.

\section{KENYA}

The Kenyan statute is identical in wording to the law of Gambia [Laws of Kenya, ch. 63, sec. 13 (Rev. 1962)]. In addition, case law has established that the defense of irresistible impulse is not recognized in Kenya [R. v. Ebrahim Weraga, 10 E.A.C.A. 48 (1943)], and that menta1 disease will be considered from precisely the same point of view as organic disease. In explaining why a particular defendant did not come within the scope of the statute, the Kenyan court said, "This is not a case where a scientific witness can say with certainty, .. as in the case of a bodily disease, from specific symptoms such as

${ }^{7}$ See, i.e., IV Laws of Uganda, ch. 106 , sec. 12 (1964). 
a rash, a coma or other physical signs, that a disease exists" [Ellis v. R. (1965) E.A.C.A. 744, 751].

Interestingly, the Kenyan courts have also held that medical evidence is not essential to prove insanity--that it is a jury question which can be answered dispositively by lay witnesses [R. V. Kibiro s/o Karioki, 25 L.R.K. 164 (1952)]. This holding seems mildly inconsistent with the strict adherence to the insanity-as-physiological disorder doctrine which is cited above. "Wrong" in the statute has been held to mean "contrary to law" and not "morally" wrong. Where the defendant claimed that what he was doing was not wrong according to tribal law, it was held that this question is an "irrelevant" one [Muswi s/o Musele v. R., 23 E.A.C.A. 622 (1956)].

The ignorance of the Kenyan courts of the role of the unconscious in human behavior is apparent in the case of R. v. Kibiegon Arap Bargutwa [6.E.A.C.A. 142 (1939)]. There the defendant was charged.with the murder of his father who, the defendant claimed, made homosexual attacks upon him. The court held that the ferocious killing by the son was not enough to vitiate responsibility via the insanity defense. . The briefest smattering of reading in Freudian psychoanalysis would show that, ordinarily, the threat of such a sexual attack from the father would so affect the son's mind that he would not know what he was doing. 8

$$
* * *
$$

There are three major sources of case law in Kenya: The East African Appeal Reports (E.A.C.A.) covering Kenya, Uganda, and Tanzania; the Kenya Criminal Revision Digest, serving as a very primary West-type digest in the major areas of criminal law; and the Digest and Guide to the Criminal Law of Kenya, 10 including most of the relevant E.A.C.A. cases, Lack of comprehensive indexing of the

${ }^{8}$ See, generally, Freud, A General Introduction to Psychoanalysis (1924); Brenner, An Elementary Textbook of Psychoanalysis (1955).

${ }^{9}$ Trevelyan, Kenya Criminal Revision Digest (1897-1964) (1965).

${ }^{10}$ Spurling, Digest and Guide to the Criminal Law of Kenya (1964). 
E.A.C.A. reports, of course, must seriously retard progress in scholarship in this area.

\section{MALAWI}

Under the laws of Nyassaland, the insanity defense is couched in the same language as the Gambla-Kenya statutes [Laws of Nyassaland, ch. 23, sec. 12 (1957)]; there is no indication that this wording has been changed in any substantial form since the nation achieved its independence as the state of Malawi.11

The few relevant reported cases repeat the M'Naughten dogma, stating explicitly: "The law laid down in $M$ 'Naughten . . . is the law of Nyassaland" [Pulumero v. R., IV Ny. L.R. 101, 102 (1.938); R. v. Eni, (1923-1960) A.L.R. Mal. 428 (1957)]. It is emphasized that this test applies to the reasonable man and not to the particular defendant charged, a formulation which again is contrary to the vast body of psychological and psychiatric thought [R. v. Chao (1923-1960) A.L.R. Ma1. 189 (1950)]. Again, medical testimony is discussed as "mere opinion" which cannot be used to establish the insanity defense unless facts can be presented to the members of the jury so that they can determine whether or not the defendant is responsible [R. V. Manda1a (1957) R\&N.L.R. 251].

$$
\text { *** }
$$

Sources are sparse in Malawi. There are a few volumes of Nyassaland Law Reports, again poorly codified; the Malawi edition of the African Law Reports, which contains some relevant cases; and the Rhodesian and Nyassaland Law Reports which emphasize the Rhodesian decisions. 12

New post-independence Malawi reports could not be found and there is apparently no relevant commentary.

${ }^{11}$ The laws of Malawi have not as yet been printed in codified form. An examination of the bound slip-sheets reveals no new penal code. However, in the new Criminal Procedure Code, a section dealing with court procedures at trial time refers to a defendant "by reason of unsoundness of mind incapable of knowing the nature of his act or that it was wrong or contrary to law." Malawi Acts "Criminal Procedure and Evidence Code," sec. 134 (1967).

12 Mandala, a Nyassaland case, is incorrectly listed In Cartwright and Read, Penal Codes of East and Central Africa and the Gambia (1963) as a N. Rhodesian case (p. 3). 


\section{TANZANIA}

Since there has been no official compilation of laws since the state of Tanzania was created, it cannot be ascertained whether or not there has been any new formulation of the penal law since that time. ${ }^{13}$ There is no indication that there has been any change from the law of either Tanganyika or Zanzibar, both of which adopted the M'Naughten formulation in the same phraseology as the states already discussed [The Laws of Tanganyika, ch. 16, sec. 13 (Rev. 1961); I The Laws of Zanzibar, ch. 13, sec. 12 (1961)].

The case law of Tanganyika is not particularly instructive--one early case merely restates the M'Naughten principles [R. v. Salim Bin Saidi, 1 T.L.R.(R.) 123 (1930)], another rejects the irresistible impulse argument [R. V. Mazabia Bin Mkomi, 8 E.A.C.A. 85 (1941)]. Another case [Republic v. Saidi Kabila Kuinga (1963) E.A.C.A. 1 (Hi.Ct.)], interestingly, points out, "The graver the alleged offense, the greater the suspicion with which the accused's own assertions of his insanity should be regarded," a position which certainly indicates, to some extent, a basic mistrust of the entire area of psychology.

The Zanzibar cases go no further in analyzing the component problems of the insanity defense. In both Zanzibar and Tanganyika, the courts limit the responsibility of a defendant claiming partial delusion to a situation which legally assumes the reality of the delusion [R. $\mathrm{V}$. Gererazi s/o Lutabingwa, 9 E.A.C.A. 56 (Tang. 1941); R. v. Mahuna bin Kashiba, 7 Z.L.R. 59 (1944)] . Here, again, the mentally ili person is treated like a reasonable person with one compartmentalized disorder which can be severed from the healthy remainder and treated in vacuo, a theory of behavior which has largely been rejected elsewhere among psychiatrists and psychologists.

$$
* * *
$$

With the exception of some E.A.C.A. cases, a smattering of Zanzibar Law Reports and a few old Tanganyika Law

${ }^{13}$ A careful examination of the session law slip-sheets of Tanzania shows no Penal Code. 
Reports, there is little source material from Tanzania. The Tanzania Law Reports have been issued in slip-sheet style (unindexed) since the state was created in 1965, but there are no cases in point. There is no applicable commentary to be found anywhere.

UGANDA

The law ${ }_{1}$ f Uganda is, again, the strict M'Naughten formulation, ${ }^{14}$ and, as in the countries already discussed, irresistible impulse is not recognized as.a.defense [R. v. Ebrahim Weranga s/o Wamala, 10 E.A.C.A. 48 (1943)]. Again, the defense will be considered as if the operative facts about which the defense was deluded were real:

Given that [defendant] believed insanely. in the wickedness of the [deceased] family, is she to be excused if knowingly she takes her revenge by killing members of that family? . . . It is the attitude of mind toward the actual deed that must be regarded. The crazy [sic] nature of the motive. which prompts the deed is, I think irrelevant [R. v. Kabande w/o Kihigue, 15 E.A.C.A. 135, 136 (1948)].

A later case notes: "There is no distinction for purposes of ascertaining criminal responsibility, between diseases which have a mental and those which have a physical origin. . . The law merely has to consider the state of mind in which the accused now is, not how he got there" [Tadeo Oyee s/o Duru v. R., (1959) E.A.C.A. $407,409,410$ (C.A.)]. Th Here again, the role of the unconscious in human behavior is totally ignored by the court, an error which cannot be overemphasized in any study of the problem of responsibility. 16

$$
* * *
$$

Source material is not quite as scarce in Uganda as in some of the other countries discussed above. Besides

${ }^{14}$ IV Laws of Uganda, ch. 106, sec. 12 (1964).

${ }^{15}$ N.B. This case is incorrectly referred to as... Dunn . . In Cartwright and Read, supra at 2 .

${ }^{16}$ See, generally, Katz, Goldstein and Dershowitz, Psychoanalysis, Psychiatry and Law (1967). 
E.A.C.A. cases (which are somewhat more plentiful here), 17 there are two hornbooks available, one of which offers only a cursory explanation of the penal code section, 18 and one which elaborates on the code deriving the M'Naughten formulation more completely. ${ }^{19}$ The 1atter book separates those exempted from mental responsibility into persons born insane and those who became insane as a result of disease or injury--a distinction which the cases seem to ignore or reject. 20

\section{ZAMBIA}

Here again the strictness with which the statute adheres to the original British law is emphasized by the courts. 21 Demeanor and lack of motive are all "unreliable" and "of little relevance" under the pure $M$ 'Naughten language [R. V. Tempi, (1961) R.\& N.L.R. 858]. Irresistible impulse is once more rejected as a defense to a criminal charge [R. V. Carson, (1957) R.\&N.L.R. 288]. "Wrong" is strictly construed as legally wrong, not morally wrong, thus depriving a defendant suffering from "paranoic psychosis" from asserting an insanity defense [Golowa v. R. (1964) R.\&N.L.R. (F.S.C. 1964)]. Insanity is seen as a jury question, not a medical question [R. V. Wolomosi Phiri, V L.R. N. 184 (1952); the fact that a defendant suffers from total amnesia (and thus cannot remember any of the circumstances connected with the offense) in no way establishes a defense at trial [R. V. Phiri, (1958) R.\&N.L.R. 1008].

In one case where it was established that a mute defendant's dumbness arose from hysteria, it was termed "a psychological disease . . an emotional disturbance, and

${ }^{17}$ There are no relevant cases in the Uganda L.R. series. 18 Brown, Criminal Procedure in Uganda and Kenya (1965). 19 Brown and Allen, An Introduction to the Law of Uganda (1968).

${ }^{20}$ Ibid., at 88 .

${ }^{21}$ I Laws of Republic of Zambia, ch. 6 , sec. 13 (1967); Laws of N. Rhodesia, Penal Cd., sec. 13 (1957). 
not a disturbance of the reason," and the defendant's insanity plea was rejected $[R$. V. Jailos Jonato, V L.R. N.R. 726 (1952)]. This explanation of hysteria is distinctly at odds with the predominant conception of that psychopathology, a neurotic disorder in which unreasonable anxiety is converted into physical symptoms as a result of unconscious conflicts. ${ }^{22}$ Again, the new dimension in psychology and psychiatry has not come to the Zambia.

$$
* * *
$$

No post-independence Zambia cases could be found. The Rhodesia and Nyassaland Law Reports contain some relevant cases, and others are reported in the Law Reports of Northern Rhodesia. Otherwise, though, there are neither hornbooks nor commentaries dealing with this subject matter.

$$
* * *
$$

In addition, there are two other sources which attempt to cover a number of notions: the Digest of East African Criminal Case Law and the Sourcebook of the Criminal Law of Africa. ${ }^{23}$ The Digest enumerates the different subject areas of criminal law in the study of Kenya, Tanzania, and Uganda, briefly synopsizing all major decisions in each area. The Sourcebook, on the other hand, appears to be closer to a genuine textbook, with a separate chapter on M'Naughten and the insanity defense. ${ }^{24}$ It includes basic materials, including the M'Naughten case, sample statutes, an article by the famed criminal law scholar Stephen, and relevant African cases--the Oyee son of Duru decision of Uganda, for example, an interesting Uganda case where an exception for witchcraft is made in a situation where the defendant lived "far away in the bush" and where he was so obsessed with being bewitched that his mind was held to be diseased [R. V. Magata s/o Kachehokano (1957) E.A.C.A. 330 (Hi.Ct. Ug.), cited at id. 3881. There are also two important Nigerian cases, to be discussed below. This is the most comprehensive

${ }^{22}$ Frazier and Carr, Introduction to Psychopathology, 142 (1964).

${ }^{23}$ Rosen and Stratton, A Digest of East African Criminal Case Law, 1897-1954 (1957); Seidman, A Sourcebook of the Criminal Law of Africa (1966). 
study of the criminal law of English speaking Africa, but still it does not deal thoroughly with most of the problems raised by the insanity defense.

\section{Modified M'Naughten}

\section{ETHIOPIA}

The relevant sections of the Ethiopian penal code read:

A person is not responsible for his acts under the law when, owing to age, illness, abnormal delay in his development or a deterioration of his mental faculties, he was incapable at the time of his act of understanding the nature or consequences of his act, or of regulating his conduct according to such understanding. [Penal Code of Ethiopia, Art. 48(1), (1957)]

He who owing to a derangement of his mind or understanding, or arrested mental development or an abnormal or deficient condition was not, at the time of his act, fully capable of understanding the nature and consequences thereof or regulating his conduct according to such understanding shall not be liable in full to the punishment. [Penal Code of Ethiopia, Art. 49(1), (1957) ]

The differences between the Ethiopian code and the M'Naughten formulation are striking. Here, the causes of not understanding the act are listed, and comprehension of the consequences of an act is as important as comprehension of the nature of the act. There are eleborate conditions upon which to premise the purging of partial responsibility, including the vague "abnormal or deficient condition."

The leading case in Ethiopia, though, interprets these statutes restrictively. When the defendant's doctor testified that the defendant was a "constitutional psychopath . . emotionally pathological .. . [on whom] the unusual amount of stress and strain is too strong . . . and may bring about an unusually pronounced tendency to yield to impulses of violence without restraint," the court rejected the insanity defense. It found two criteria upon which it could base its decision: psychological criteria affecting intelligence and psychological criteria affecting volition. Since it found that the 
defendant fully understood the nature and consequences of his acts and merely was inclined to use less resistance than another person, it affirmed his conviction [Ato Getatchew Gizaw v. Adv. Gen'1, Sup. Imp. Ct. (1959), 1 J. Eth. L. 11 (1964)] .

A commentator has formulated a "biophysical method" for interpretation of the insanity defense statute: a person is irresponsible when he is in such physical or mental condition (biological cause) that he is totally deprived of his mental faculties (psychological effect); these two must be linked by causal relation. 25 In addition, he showed awareness of a major concept in the area of mental illness: "Between insanity and sanity, which in any event are conditions whose frontiers are imprecise, there exist intermediate stages." 26 Too often the M'Naughten principle ignores these crucial intermediate stages--the gray area in which most of mankind is of ten operative. The limited responsibility statute, if availed of, can prove to be a significant development in this area of the law.

$$
* * *
$$

There are two major--and reputable--sources in Ethiopia: Lowenstein's Materials on Comparative Criminal Law and Graven's Introduction to Ethiopian Penal Law. Lowenstein's text compares the Ethiopian and the Swiss penal systems and includes relevant statutes, cases (there are few in this area) and articles (including a perceptive and far-reaching attack on M'Naughten). 29 Graven's work, an elaborate and complete analysis of the penal code, interprets each section fully and is one of the major works of scholarship in the field of African criminal law.

\section{LIBERIA}

In the Liberian code, "an act otherwise criminal done by a person who is an idiot imbecile, lunatic or who is insane is not a crime." 28 To come within this section,

${ }^{25}$ Graven, An Introduction to Ethiopian Penal Law, 134 (1965).

${ }^{26}$ Ibid., at 136 .

27 Weihofer, "Mental Disorder as a Criminal Defense," in Lowenstein, op. cit., 161. 
it must be shown that, at the time of committing the alleged crime, the defendant "was laboring under such defects of understanding as not to know either a) the nature of the act he was doing or b) that the act was wrong." 29

There is a severe lack of relevant cases which have interpreted the statute section. The only case law holds that insanity must be proven by a medical expert, not merely by law witnesses [Carew V. Jessenah, 13 L.L.R. 168 (1958)]; that murder (implying intent) must be committed by a person of "sound memory and discretion" [Padmore v. Republic, 3 L.L.R. 418, 421 (1933)]; and that it would be a reasonable error if the trial court denied the defendant (charged with murder in the first degree) the right to produce witnesses to testify that he suffered from temporary spells of insanity [Tay v. Republic, 9 L.L.R. 92 (1945)]. Other than these cases, there are neither reported decisions nor comments on the Libaria insanity law.

$$
\text { * * * }
$$

The Cornel1 University Law School has completed a codification of the Liberian statutory materials (non-annotated). Unfortunately the cases have been neither systematically reported nor collated and, as a result, there is little information which can be gleaned. No commentary of any sort on the criminal law of Liberia could be found.

\section{Non-M'Naughten}

\section{SOMAL I}

The Somali Penal Code states: "Whoever at the moment when he committed an act was by reason of infirmity in a state of mind such as to preclude capacity, understanding and volition shall not be liable." 30 In addition, it provides: "No one may be punished for an act or omission - . unless he has done it knowingly or willfully."31 This latter provision is referred to as the "psychological element" which consists of "wilful and conscious.intent." 32

29

Id., sec. 15 .

${ }^{30}$ Angeloni, The Somali Penal Code, sec. 50 (1967).

${ }^{31}$ Id., sec. $23 . \quad 32$ Id. at 13. 
Although there are netiher cases nor commentary, it appears that "capacity, understanding and volition" is a broad test, going far beyond the "nature of the act" scope of $M$ 'Naughten. The inclusion of "conscious" intent as a prerequisite for a volitional act is also of great significance--it acknowledges sub silentio that behavior is often determined by unconscious impulses and motivations and that such behavior cannot be treated as arising from intentional actions. If this explanation is ever given wide interpretation it would prove to be a major break with the past in the field of the insanity defense. Unfortunately there has been an utter lack of scholarship here, so there can only be conjecture as to how the code will ultimately be interpreted by the courts.

\section{SUDAN}

In the Sudan, "No act is an offense which is done by a person who at the time of doing it did not possess the power of appreciating the nature of his acts or of controlling them by reason of a permanent or temporary insanity or mental infirmity." 33

Here the courts have squarely held: "Our law is different from England's. We do not recognize the English test of the lack of knowledge that the act the defendant does is wrong or contrary to law" [Sudan Gov't v. Mousa Adam Ishag, (1958) S.L.J.R. 1,2] Under section 50, nature is meant to imply both "quality" and the "operator of external agencies." Schizophrenia [Sudan Gov't v. Mousa Adam Ishag, (1958) S.L.J.R. 1,2], paranoid delusion [Sudan Gov't v.. Gabia Angello Dafaalla, (1961) S.L.J.R. 32], and epileptic fits inducing unconsciousness [Sudan Gov't v. Ahmed E1 Obeid Saghayroun, (1961) S.L.J.R. 123] were held to come within the scope of the statute. In addition, where someone was emotionally unstable to an abnormal degree and suffering from melancholia, but not "wholly destitute of the use of reason," he was not excused totally (section 50), although punishment was mitigated as a result of partial insanity [Sudan Gov't v. Nafisa Dafalla Mohamed, (1961) S.L.J.R. 199]. 
The administrative branch of the court system even suggested a test to determine insanity:

a) at the time of the act did the defendant possess the power of appreciating the nature of the act? it?

b) if so, did he possess the power of controlling

c) if the answer to a) or b) is 'no' was his

inability to appreciate or control the result of permanent or temporary insanity or mental infirmity?

[Sudan Gov't v. Khidir Abdalla E1 Husseir, (1966)

S.L.J.R. 110]

In addition, of course, the Sudanese code expressly recognizes the defense of irresistible impulse (see f. 33, supra). Clearly, the English rule and the English methodology have been fully discarded. Other African jurisdictions might do well to examine the case law which has built up here and consider it as a partial model for their own penal systems.

$$
* * *
$$

The Sudan Law Journal Reports are a relatively comprehensive compilation of relevant cases and articles for the last decade. Before 1959, though, there is little available information. The Sudan Law Reports, beginning in 1900 , offer no cases whatsoever in this area.

There is one significant commentary comparing the Sudanese and Northern Nigeria Penal Codes which effectively, if briefly, summarizes the law of the Sudan (especially as it differs from $M^{\prime}$ Naughten) in this area. ${ }^{3}$

GHANA

In a unique statutory formulation, the Ghana code reads:

When a person is accused of crime, [he can plead insanity]--

a) if he was prevented, by reason of idiocy, imbecility, or any mental derangement or disease affecting the mind, from knowing the nature or consequences of the act in respect of which he is accused; or

${ }^{34}$ Gledhill, The Penal Codes of Northern Nigeria and the Sudan (1963). 
b) if he did the act under the influence of an insane delusion of such a nature as to render him an unfit subject for punishment of any kind. [Criminal Code of Ghana, Act 29, sec. 27 (1960)]

It is apparent that this test goes beyond M'Naughten in its inclusion of imbecility and idiocy, and in its focus on the consequences, as well as the nature, of the act. The test becomes, in effect, one of "foreseeability": does the defendant have the capacity to foresee the results of his conduct? Under the first section of the test, a unity of the mind, not the fragmentation of the cognitive function envisioned by $M$ 'Naughten, is contenplated. Under the second section, the defense of irresistible impulse is permitted. 35

Case law in Ghana has been somewhat surprisingly inconsistent in view of the enlightened statute. Where the defendant had an insane delusion that his father had hurt his mother and hated him, the court held that, since punishment would be pointless, the delusion was sufficient for the insanity defense [St. V. Ayaabi Kusasi, Jan-June Cyclostyled Judgments 56 (Ct. App. 1958)]. It was also held, in an early case, that occurrence of a lucid interval would not negate evidence of prevailing insanity, since the court said that it was commonplace "for an insane person to be occasionally 'calm"" [R. v. Grumah, 1 G.L.R. 307 (1959)]. The courts reversed direction to some extent, though, in finding that insanity was purely a jury question for lay witnesses [R. $\mathrm{V}$. Kwandwo Mensah, 1 G.L.R. 309 (1959)], and that hysterical amnesia (a severe neurotic disorder) could not be used to support a plea of insanity [R. v. Yeboah, 1 G.L.R. 434 (1959)].

In its most anachronistic decision the court disallowed the insanity defense in a case where it was conceded defendant Dagarti had insanity delusions and where he heard others singing tribal songs about hifs alleged impotency (a clear symptom of paranoia). 36 Here the court, in a M'Naughten-like holding, found that, to come

${ }^{35}$ See, generally, Seldman, "Insantty as a Defense Under the Criminal Code of 1960," 1 U. Ghana L.J. 42 (1964).

${ }^{36}$ Frazier and Carr, op. cit., at 143. 
under the section 27 (b), the delusion must be of such a nature that if the imagined facts were true they would provide justification for the action taken as a result of the delusion [Kwame Dagarti, July-Dec. Cyclostyled Judgments 15 (S.Ct. 1960)].

After this low-water mark, though, the cases began a gradual upswing. In a case where it held that the nature of the insanity and not the form which the delusion takes is the controlling factor, the court reaffirmed the earliest cases and ignored Dagarti [Sergeant Bodie, Crim. App1. 31/33 (1964)]. This was buttressed by a later decision which, citing the early cases, approved of the irresistible impulse defense and noted that the essence of the insane delusion cases is the state of mind of the defendant, not what the situation would be if the imagined facts were true [St. v. Yaw Manu \& Yaw Owurso, 3 Curr. Cases PP 106 (S.Ct. 1965)]. Finaliy, the Dagarti case was expressly overruled in State v. Akpawey, a 1966 decision. The court noted:

To punish a person in [a deluded] state of mind, whether the purpose be deterent, preventive, reformative or retributive, ridicules the law.

It is the degree or quality of the incapability of the mind which caused the delusion and not the nature of the subject or the substance of the particular delusion which decides the issue.

If the state of mind which hatched the delusion is such that imposition of the normal punishment provided for the offence committed will not serve any of these [jurisprudential] purposes, the punishment will be pointless. [St. v. Akpawey, 4 Curr. Cases PP 87 (S.Ct. 1966)]

It is hoped that the Ghana courts will follow the lead of this case by allowing Dagarti to remain buried and by continuing to adhere to the more enlightened procedures set down in these most recent cases.

$$
* * *
$$

Relevant cases can be found in the Ghana Law Reports and in the slip-sheet Cyclostyled Judgments and Current Cases . None of the latter, unfortunately, are codified or indexed, so the material loses much of its potential 
research value. The University of Ghana Law Journal has dealt comprehensively with the subject of insanity at least once--it must be condensed as potential source material for the future.

Milner's work on African penology ${ }^{37}$ deals with the law of Ghana in this area but must be considered extremely critically, in view of the fact that the post-1960 cases are mentioned only in passing.

As in the Sudan, the case law of Ghana should be compulsory reading for the law revision committees and courts of the other African countries.

\section{NIGERIA}

Under the penal codes of Nigeria and the Western Region of Nigeria 39 it is stated that:

A person is not criminally responsible for an act or omission if at the time of doing the act he is in such a state of mental disease or natural mental infirmity as to deprive him of the capacity to understand what he is doing or of capacity to control his actions or of capacity to know that he ought not to do the act.

\section{${ }^{37}$ See n. 5 , supra.}

${ }^{38} \mathrm{~A}$ reading of Milner would indicate that the Dagarti case is still the law of Ghana. He cites Sergeant Bodie and Akpawey in a footnote but ignores both their relevance and the latter's express overruling of Dagarti. Id. at 335 and $n .101$ at 359 .

${ }^{39}$ The Northern Region envisions a different test: "Nothing is an offense which is done by a person who at the time of doing it, by reason of unsoundness of mind, is incapable of knowing the nature of the act, or that he is doing what is either wrong or contrary to law." The Laws of Northern Nigeria, sec. 51 (1965). As interpreted, this law is treated like M'Naughten, with the additional defense of irresistible impulse. Gledhill, supra at 96. However, this is limited in application to the northern region of the country. 
A person whose mind at the time of his doing or omitting to do an act is affected by delusions on some specific matters, but who is not otherwise entitled to the benefit of the foregoing provisions of this section, is criminally responsible for the act to the same extent as if the real state of things had been as he was induced by the delusions to believe to exist. [Nigerian Criminal Code, sec. 28 (Rev. 1963); Western Region of Nigeria Criminal Code, sec. 26 (1963)]

In the leading case of Sunday Omoni, it is expressly stated that the Nigerian code is not the same as $M$ 'Naughten because of the inclusion of "natural mental infirmity" in the Nigerian test and by allowing "incapacity to control his actions" to relieve a defendant from criminal responsibility [R. v. Sunday Omoni, 12 W.A.C.A. 511 (1949)]. Clearly, the "incapacity" contemplated goes beyond the questions of cognition and legal right or wrongness. M'Naughten is also departed from in those cases holding that the defense of irresistible impulse is available here [R. v. Nasamu, 6 W.A.C.A. 74 (1940)].

In other cases, it is held that the evidence of insanity of ancestors or blood relations is admissible (another step never contemplated by M'Naughten), although medical evidence is not essential [R. V. Inyang, 12 W.A.C.A. 5 (1946) ]. Although, generally, the question of motive is immaterial, where there is sufficient evidence indicative of insanity the absence of any evidence of motive may become relevant to the point at issue [R. V. Ashigifuwo, 12 W.A.C.A. 389 (1948)].

In a somewhat contrary decision, the court rejected an insanity plea where it held that "the illness which the defendant was suffering from was pain in the body and not any disease of the mind" [Dim v. R., 14 W.A.C.A. 154 (1952)], not a particularly enlightened reading of the law, where the defendant suffered from hysterical amnesia. However, in a more recent decision, the court accepted the insanity plea where the defendant's medical witness asserted that the defendant's persecution complex was "a paranoid delusion disorder". [Att'y Gen'1 v. Titi Owhofejeobu, V Nigerian Bar J. 73 (1964)].

Generally, then, the courts in Nigeria appear to be aware that they are taking the direction away from M'Naughten and that new dimensions to the problems of criminal responsibility have arisen in the last century. 


\section{$\star \star *$}

No other country in English-speaking Africa has the wealth of literature in this area as does Nigeria. Brett and McLean 40 analyze the relevant statutes, reproduce the significant cases and offer commentary on the problems raised. Aguda 41 delves deeply into the question of mental responsibility, noting that under the Nigerian code, "senile and depressive psychosis - D schizophrenia and,
neuroses" may all be sufficient to eliminate liability. Hedges analyzes the impact of the Sunday Omoni $4 \xi^{\text {ase and }}$ considers the other key decisions cited above. 43 okonkwo and Naish 44 discuss the problems inherent in attempting to define legal terms by medical principles and suggest wisely: "The definition of criminal responsibility should. be left reasonably flexible so as to allow for changing standards and progress in knowledge." 45 In addition, they recite other African cases and some American decisions (including Durham), a practice which should be emulated by more text writers.

Okonkwo and McLean present a casebook on criminal law which devotes a chapter to the problems of responsibility. ${ }^{46}$ As one of the first such casebooks in its field, it must be strongly commended for its attempts to bring the relevant criminal cases to the law student of Nigeria.

Case sources similarly abound in Nigeria. The West African Appeal Cases (W.A.C.A.) predominate--they are

${ }^{40}$ Brett and McLean, The Criminal Law and Procedure of Lagos, Eastern Nigeria and Western Nigeria (1963).

${ }^{41}$ Aguda, Principles of Criminal Liability in Nigerian Law (1965).

${ }^{42}$ Id. at 267 .

${ }^{43}$ Hedges, Introduction to the Criminal Law of Nigeria (1962).

${ }^{44}$ Okonkwo and Naish, Criminal Law in Nigeria (1964). ${ }^{45}$ Id. at 129 .

${ }^{46}$ oknokwo and Mclean, Cases on the Criminal Law, Procedure and Evidence of Nigeria (1966). 
cumulatively indexed in fifteen year periods. There are also Nigeria Law Reports, Nigerian Monthly Law Reports (dealing primarily with the Western Region), Law Reports of the High Court of the Federal Territory of Lagos, Federal Supreme Court Reports, Western Region Law Reports, a Nigerian Law Journal (dedicated to presenting cases of "great topical interest") and the Nigerian Bar Journal. Clearly, a relationship between the proliferation of cases and of literature can be found in at least this one case.

$$
* * *
$$

\section{CONCLUSIONS}

In summary, 47 it appears that the courts of Africa have been derelict in taking notice of the new knowledge of human behavior. Although there are some exceptions, generally the dereliction on the part of the courts is somewhat inversely proportional to the amount of reported cases and secondary source materials. The fact, though, that there are a few countries which have made major advances in the field of mental responsibility indicates that it is not a hopeless task which faces the courts of Africa, merely one which will require the explicit discarding of over 100 years of law and dogma.

${ }^{47}$ Sierra Leone was not considered since neither cases, commentary nor statutory material could be obtained. The one relevant statute dealing with the presentation of the insanity defense at trial only speaks in passing of one "insane so as not to be responsible for his act." However, neither insanity nor responsibility are in any way defined. I Laws of Sierra Leone, ch. 39, sec. 66 (1960). 